\title{
Article
}

Arq Neuropsiquiatr 2010;68(2):216-223

\section{Prevalence and management of headache in a selected area of Southern Santa Catarina}

\author{
Taís dos Santos Corrêa', Kelly Miranda dos Santos', Dayani Galato²
}

\begin{abstract}
Headache is a worldwide health problem which affects quality of life. Objective: To identify the prevalence and management of headache and examine its impact. Method: A crosssectional study with 240 participants was performed to collect data related to (a) headache occurrence, (b) its impact through the "Migraine Disability Assessment Test" (Midas), and (c) headache management. Results: Last year prevalence (2008) was $64.6 \%$. There was a low Midas score in $80.6 \%$ of cases. With regard to headache management, $86.4 \%$ of respondents said that they use medicines, mainly analgesics (73.9\%). Prescribed medicines were used in $31.0 \%$ of cases, although $72.4 \%$ of those were old prescriptions. Headache was associated with gender $(p=0.0002)$, occupation $(p=0.0109)$ and mean age $(p=0.0083)$, while the Midas score was associated with pain intensity $(p=0.0069)$ and the use of drugs only during headache crisis $(p=0.0464)$. Conclusion: There was a high prevalence of headaches and a low level of disability among the population studied, being the management based on self-medication.
\end{abstract}

Key words: headache, self-medication, prevalence.

\section{Prevalência e manejo de cefaléias em um município do sul de Santa Catarina}

\section{RESUMO}

As cefaléias constituem um problema de saúde mundial que afeta a qualidade de vida. Objetivo: Identificar a prevalência de cefaléias, conhecendo seu impacto e manejo adotado. Método: Estudo transversal com 240 participantes, coletando-se dados relacionados à ocorrência de cefaléia; impacto através do Migraine Disability Assessment Test (Midas); e manejo. Resultados: A prevalência no último ano (2008) foi 64,6\%. O escore do Midas foi pequeno em 80,6\% dos casos. Em relação ao manejo, $86,4 \%$ dos entrevistados utilizavam medicamentos, principalmente, analgésicos (73,9\%). Em 31,0\% das situações o medicamento foi prescrito, sendo que destas, $72,4 \%$ eram prescrições antigas. A cefaléia associou-se com gênero ( $p=0,0002)$, situação profissional $(p=0,0109)$ e média de idade $(p=0,0083)$ e o Midas com intensidade da dor $(p=0,0069)$ e uso de medicamentos apenas na crise $(p=0,0464)$. Conclusão: Houve alta prevalência de cefaléias e baixo grau de inaptidão na população estudada, sendo o manejo baseado na automedicação.

Palavras-chave: cefaléia, automedicação, prevalência.

Headache is a health problem worldwide which can affect individuals of all age groups and both genders ${ }^{1-3}$. Very few people will experience no headache crisis during their lifetime. Headache prevalence is higher among women ${ }^{1}$, being related to gender $^{4,5}$ as well as to other factors, such as the use of hormonal birth control pills, white people ${ }^{4}$, low economic level, divorce or widowhood ${ }^{5}$, somatic symptoms ${ }^{6}$, menstrual cycle $\mathrm{e}^{7}$, presence of comorbidities and higher risk for mental illness and other pain conditions ${ }^{8}$. For some, headaches become a limiting condition that interferes 
with their quality of life, affecting professional activities, as well as social and affective relationships ${ }^{9}$. The Migraine Disability Assessment Test (Midas) ${ }^{10}$ was used to examine the impact of headache on different aspects of individuals' life. Through five questions, this instrument measures the individual's disability caused by headaches, taking labor absence and productivity reduction in the last three months as parameter. This instrument was translated into Portuguese and validated for headache assessment ${ }^{11}$.

Because headaches interfere with daily life, a large number of patients seek treatment outside health care institutions, mainly through self-medication and advice from friends and family. In Vitoria/ES, it was observed that $69.9 \%$ of respondents with headache used common painkillers, among which sodium dipyrone $(26.8 \%)$ and paracetamol $(25.5 \%)^{12}$ were the most frequently mentioned. In addition to pharmacological management, individuals may use non-pharmacological management, such as rest ${ }^{13}$, physiotherapy ${ }^{14}$ and acupuncture ${ }^{15}$.

This study aimed to identify the prevalence and management of headaches among individuals living in a municipality in southern Santa Catarina and examine the impact on their daily lives.

\section{METHOD}

A cross-sectional study was carried out using interview technique in public places of Tubarão/SC, including squares, university, health care units, bus terminals, among others, as performed by Domingues and colaborators $^{12}$. This method requires a convenience sample which was selected among the population of 92,569 inhabitants according to the census conducted by the Brazilian Geography and Statistics Institute (IBGE) in 2007.

Sample size was determined by the estimated prevalence of headache of $80.8 \%$ as indicated by Queiroz and collaborators ${ }^{5}$. Considering a significance level of $95 \%$ and an error of 5\%, sample size of 238 individuals was determined, using the Epi Info ${ }^{\mathrm{TM}}$ version 6.0. Inclusion criteria required participants to be 18 years and over, live in the selected area and accept to participate in the study by signing the term of free and informed consent.

The data collection instrument was composed of both open-ended and closed questions, which aimed to gather information regarding the individual's profile such as age, gender, criteria for economic classification ${ }^{16}$, marital status, occupation, etc.; the occurrence of headache and its characteristics according to the International Headache Society ${ }^{17}$, the Brazilian Headache Society ${ }^{18}$, and Maranhão-Filho ${ }^{19}$, such as frequency, duration, intensity, location, type of pain and factors (triggering, accompanying and aggravating); the impact of headache on the individual daily life using the Midas ${ }^{10,11}$ scores; and the type of disorder management used. In case of medication intake, the type, frequency, drug indication, and reuse of old prescriptions was assessed.

A pilot study with ten individuals living in other municipalities and, therefore, not included in the sample, was carried out to check the appropriateness and readability of the questions. There was no need for change and so the instrument was approved.

Initially, a database containing the variables of the study was created, which was subsequently evaluated to determine the prevalence of headaches and the profile of respondents. To study data association, chi-square tests were used for proportions and analysis of variance for mean comparisons. A significance level of $5 \%$ was used.

This study was approved by the Research Ethics Committee of the University of Southern Santa Catarina under the code number 08.495.4.06.III.

\section{RESULTS}

The sample comprised 240 individuals aged 18 to 77 years (mean $41.7 \pm 15.8$ years), the majority out of which were Caucasian (94.6\%), married (45.8\%), had children (65.0\%), and lived with their families (86.6\%). Regarding the economic level, $57.0 \%$ belonged to categories $C$ and $\mathrm{D}$, according to the Brazilian Economic Classification Criterion $^{16}$ (Table 1).

The population under study consisted mainly of women $(71.2 \%)$. As to the variables for menstruation and oral contraceptive use, it was observed that $57.3 \%$ of women had regular menses in the last 3 months and $35.1 \%$ were using oral contraceptives.

The individuals' clinical profile was characterized by self-reported health problems as described in Table 1.

Last year prevalence of headaches was $64.6 \%$ (95\% confidence interval: 70.6-58.5), corresponding to a total of 155 reported cases.

Table 2 shows headache characteristics in the study population. A positive family history of headache was found in $64.3 \%$ of headache sufferers. Interviewed individuals had been affected for $11.7( \pm 12.5)$ years on average; some reported that headaches had started a few months ago, while others had been suffering for as long as five decades. With regard to the most common headache characteristics, data show that they occur every month (32.2\%), last for hours (48.4\%), are of moderate intensity (37.4\%) and are reported constant (76.6\%).

In some cases $(24.0 \%)$, the presence of previous pain symptoms, such as dizziness (13.5\%) and aura (13.5\%) pointed to the beginning of a crisis, triggered primarily by emotional disorders (61.7\%) and hormonal imbalances (37.7\%). Emotional stress (65.2\%) was found to exert significant influence on headache occurrence, while as intolerance to sound (52.2\%) and light (48.4\%) were commonly mentioned as shown in Table 3 . Data collect- 
Table 1. Sample description according to socioeconomic and demographic variables $(n=240)$.

\begin{tabular}{|c|c|c|c|}
\hline Characteristics & Description & $\mathrm{n}$ & $\%$ \\
\hline Age & $\begin{array}{l}<30 \\
30-55 \\
>55\end{array}$ & $\begin{array}{c}75 \\
114 \\
51\end{array}$ & $\begin{array}{l}31.3 \\
47.5 \\
21.2\end{array}$ \\
\hline Gender & $\begin{array}{l}\text { Male } \\
\text { Female }\end{array}$ & $\begin{array}{c}69 \\
171\end{array}$ & $\begin{array}{l}28.8 \\
71.2\end{array}$ \\
\hline Marital status & $\begin{array}{l}\text { Married } \\
\text { Widow/er } \\
\text { Divorced } \\
\text { Unmarried } \\
\text { Stable relation }\end{array}$ & $\begin{array}{l}110 \\
16 \\
22 \\
84 \\
8\end{array}$ & $\begin{array}{c}45.8 \\
6.7 \\
9.2 \\
35.0 \\
3.3\end{array}$ \\
\hline Economic classification* & $\begin{array}{l}\text { A1 } \\
\text { A2 } \\
\text { B1 } \\
\text { B2 } \\
\text { C1 } \\
\text { C2 } \\
\text { D } \\
\text { E }\end{array}$ & $\begin{array}{c}0 \\
6 \\
27 \\
70 \\
83 \\
43 \\
11 \\
0\end{array}$ & $\begin{array}{c}0.0 \\
2.5 \\
11.3 \\
29.2 \\
34.5 \\
17.9 \\
4.6 \\
0.0\end{array}$ \\
\hline Schooling & $\begin{array}{l}\text { Illiterate or up to the } 3^{\text {rd }} \text { grade } \\
\text { Up to } 4^{\text {th }} \text { grade } \\
\text { Primary school } \\
\text { High school } \\
\text { Higher education }\end{array}$ & $\begin{array}{l}21 \\
50 \\
41 \\
96 \\
32\end{array}$ & $\begin{array}{r}8.8 \\
20.8 \\
17.1 \\
40.0 \\
13.3\end{array}$ \\
\hline Residency & $\begin{array}{l}\text { With family } \\
\text { Alone } \\
\text { With friends }\end{array}$ & $\begin{array}{c}208 \\
27 \\
5\end{array}$ & $\begin{array}{l}86.6 \\
11.3 \\
2.1\end{array}$ \\
\hline Health problem reported & $\begin{array}{l}\text { Yes } \\
\text { No }\end{array}$ & $\begin{array}{c}98 \\
142\end{array}$ & $\begin{array}{l}40.8 \\
59.2\end{array}$ \\
\hline $\begin{array}{l}\text { Most frequent } \\
\text { health problems }\end{array}$ & $\begin{array}{l}\text { Arthritis } \\
\text { Depression } \\
\text { Diabetes } \\
\text { Hypertension }\end{array}$ & $\begin{array}{l}10 \\
21 \\
13 \\
37\end{array}$ & $\begin{array}{r}4.2 \\
8.8 \\
5.4 \\
15.4\end{array}$ \\
\hline $\begin{array}{l}\text { Most frequently used } \\
\text { medications ( } n=175)\end{array}$ & $\begin{array}{l}\text { A - Food and metabolism } \\
\text { C - Cardiovascular system } \\
\text { G - Genito-urinary system and sex hormones } \\
\text { N- Nervous system }\end{array}$ & $\begin{array}{l}18 \\
41 \\
26 \\
41\end{array}$ & $\begin{array}{l}10.3 \\
23.4 \\
14.9 \\
23.4\end{array}$ \\
\hline $\begin{array}{l}\text { Headache-related } \\
\text { medications }{ }^{* *}(n=175)\end{array}$ & $\begin{array}{l}\text { Calcium channel blockers } \\
\text { Nitrates }\end{array}$ & $\begin{array}{l}1 \\
2\end{array}$ & $\begin{array}{l}0.6 \\
1.2\end{array}$ \\
\hline
\end{tabular}

*Brazilian Economic Classification ${ }^{15}$; **Described by Thomson ${ }^{19}$.

ed on headaches suggest that they are mainly migraine and tension-type.

The Midas score was less than 5 in $80.6 \%$ of those who reported headache in the last year, having little or no disability as it can be seen in Table 2 .

With regard to the type of management used, $86.4 \%$ of individuals reported the use of medicines, being painkillers $(73.9 \%)$ the most frequent, especially paracetamol and dipyrone sodium, and muscle relaxants (12.8\%), such as orfenadrina and combinations. These results can be seen in Table 4. It should be noted that the chronic use of analgesics for 15 days or more was mentioned by $12.9 \%$ of these individuals, nonetheless, in this study there was no significant association between the frequent use of medications and daily headache ( $\mathrm{p}=0.0898)$.

The use of medications for headache management was observed predominantly during the crisis $(80.6 \%)$, being the same medication used for years $(78.1 \%)$ or months (11.2\%), which led to headache improvement $(66.3 \%)$ or relief (19.8\%).

Data showed that only $31.0 \%$ of individuals who manage headache with the use of medications were taking prescription drugs, of which $72.4 \%$ said they reused old prescriptions. In the headache management with the use of drugs, the main sources of information for their use included medical advice (28.3\%), followed by suggestions 
Table 2. Characteristics of headaches and disability level of individuals (MIDAS).

\begin{tabular}{|c|c|c|c|}
\hline Characteristics & Description & $n$ & $\%$ \\
\hline Headache frequency $(n=155)$ & $\begin{array}{l}\text { Daily } \\
\text { Weekly } \\
\text { Monthly } \\
\text { Sporadic }\end{array}$ & $\begin{array}{l}26 \\
39 \\
50 \\
40\end{array}$ & $\begin{array}{l}16.8 \\
25.2 \\
32.2 \\
25.8\end{array}$ \\
\hline Headache duration $(n=155)$ & $\begin{array}{l}\text { Seconds } \\
\text { Minutes } \\
\text { Hours } \\
\text { Days } \\
\text { Weeks } \\
\text { Constant }\end{array}$ & $\begin{array}{c}1 \\
30 \\
75 \\
44 \\
1 \\
4\end{array}$ & $\begin{array}{c}0.6 \\
19.4 \\
48.4 \\
28.4 \\
0.6 \\
2.6\end{array}$ \\
\hline Intensity ( $n=155$ ) & $\begin{array}{l}\text { Mild } \\
\text { Moderate } \\
\text { Severe }\end{array}$ & $\begin{array}{l}45 \\
58 \\
52\end{array}$ & $\begin{array}{l}29.1 \\
37.4 \\
33.5\end{array}$ \\
\hline Location of pain $(n=154)$ & $\begin{array}{l}\text { Unilateral } \\
\text { Alternating between one and two sides } \\
\text { Bilateral } \\
\text { In front } \\
\text { Behind } \\
\text { In front and behind }\end{array}$ & $\begin{array}{c}27 \\
27 \\
55 \\
36 \\
7 \\
2\end{array}$ & $\begin{array}{r}17.5 \\
17.5 \\
35.7 \\
23.4 \\
4.5 \\
1.4\end{array}$ \\
\hline Type of pain $(n=154)$ & $\begin{array}{l}\text { Constant } \\
\text { Chocks } \\
\text { Burning } \\
\text { Pressure }\end{array}$ & $\begin{array}{c}118 \\
23 \\
11 \\
2\end{array}$ & $\begin{array}{l}76.6 \\
14.9 \\
7.1 \\
1.4\end{array}$ \\
\hline $\begin{array}{l}\text { Degree of disability according } \\
\text { to the MIDAS score }(n=155)\end{array}$ & $\begin{array}{l}\text { Little or no disability (score } 0-5 \text { ) } \\
\text { Mild disability (score 6-10) } \\
\text { Moderate disability (score 11-20) } \\
\text { Severe disability (score > } 21 \text { ) }\end{array}$ & $\begin{array}{c}125 \\
14 \\
8 \\
8\end{array}$ & $\begin{array}{c}80.6 \\
9.0 \\
5.2 \\
5.2\end{array}$ \\
\hline
\end{tabular}

MIDAS: migraine disability assessment test.

Table 3. Main factors related to headaches.

\begin{tabular}{llcc}
\hline Characteristics & Description & $\mathrm{n}$ & $\%$ \\
\hline Main triggering factors $(\mathrm{n}=154)$ & Emotional changes & 95 & 61.7 \\
& Sunlight exposure & 11 & 7.1 \\
& Delay in food intake & 44 & 28.6 \\
& Sleep schedule changes & 35 & 22.7 \\
& Food and diet products & 21 & 13.6 \\
& Vicious positions of the neck & 24 & 15.6 \\
& Hormonal changes & 58 & 37.7 \\
Main accompanying factors ( $\mathrm{n}=155)$ & Intolerance to light & 75 & 48.4 \\
& Intolerance to sounds & 81 & 52.2 \\
& Intolerance to odors & 49 & 31.6 \\
& Nausea & 62 & 40.0 \\
& Vomiting & 36 & 23.2 \\
& Lowering of one of the eyelids & 21 & 13.5 \\
& Tearing and redness in the eyes & 34 & 21.9 \\
& Nasal congestion or rhinorrhea & 13 & 8.4 \\
& Physical activity & 30 & 19.3 \\
Main aggravating factors $(\mathrm{n}=155)$ & 101 & 65.2 \\
& Emotional stress & 63 & 40.6 \\
& Noise & 44 & 28.4 \\
& Odors & 37 & 23.8 \\
\hline
\end{tabular}


Table 4. Management of headaches.

\begin{tabular}{llcc}
\hline Characteristic & Description & $\mathrm{n}$ & $\%$ \\
\hline Management used & Nothing & 14 & 9.0 \\
$(\mathrm{n}=155)$ & Medications & 134 & 86.4 \\
& Non-pharmacological & 40 & 25.8 \\
Pharmacological classes & M01A - Non-steroidal antiinflammatory & 16 & 8.6 \\
mentioned ( $\mathrm{n}=187)$ & M03 - Muscle relaxants of central action & 24 & 12.8 \\
& N02- Painkiller & 138 & 73.9 \\
& Others & 6 & 3.1 \\
Unknown & 3 & 1.6 \\
medications ( $\mathrm{n}=134)$ & Orfenadrina and combinations (M03BC51) & 22 & 16.4 \\
& Acetylsalicylic acid (N02BA01) & 10 & 7.5 \\
& Dipyrone sodium (N02BB02) & 39 & 29.1 \\
& Propifenazona and combinations (N02BB54) & 8 & 6.0 \\
& Dipyrone and combinations (N02BB72) & 7 & 5.2 \\
& Paracetamol (N02BE01) & 52 & 38.8 \\
\hline
\end{tabular}

from friends, neighbors and relatives (27.9\%), and orientation obtained in pharmacies (24.4\%).

Non-pharmacological management of headache was adopted by $25.8 \%$ of individuals and included the use of compresses and resting in bed, which resulted in crisis improvement or at least headache relief.

The results of the statistical tests performed to determine associations between variables studied can be seen in Table 5.

\section{DISCUSSION}

In this study we chose to use the methodology employed by Domingues and collaborators ${ }^{12}$, interviewing people in public places of the municipality. The adoption of this methodology represented a limiting factor, since it is not a population-based study. On the other hand, as an exploratory study, it allowed examining the profile of patients with headaches in the municipality and pain management methods used to deal with this problem so far unknown. The possibility of underestimation of headache prevalence during the study period when compared to individuals' lifetime should also be noted. Those with appropriate treatment or in the absence of the triggering factor have responded negatively to headache incidence in the previous year. This situation would not have occurred had they been asked about the incidence of headache during their lifetime. In addition, another limiting possibility would be the forgetfulness of the period in which the crisis have occurred, if before or after the cutoff period set in this study. It is also important to emphasize that this study was focused on the complaint of headache and not on its diagnostic classification.

However, the study is important for determining prevalence and factors associated with headache, such as management and disability. It constitutes a new research in the region and can help optimize public service deliv- ery that meets the demand of individuals with headache, since a great number of individuals who were not yet assisted by the health services were included in this study. The high cost of headaches for the public health system as demonstrated by Bigal and collaborators ${ }^{21}$ in a municipality in the state of São Paulo, where headaches are responsible for $7.9 \%$ of consultations in primary health care units, $9.7 \%$ in the ER and $1.1 \%$ of hospital admissions in the public health system, reinforces the importance of epidemiological studies for planning health care strategies.

The results showed a high prevalence of headaches in the population studied, which corroborates other studies developed in the country ${ }^{4,5,22}$, in which prevalence rates ranged from 48.1 percent to 80.8 percent.

Another factor confirmed by this study was the higher prevalence of headache among women, which has also been found in other studies ${ }^{1,4,5}$ in which pain is often associated with emotional or hormonal triggering factors. Also related to the fact of being women, the use of oral contraceptive or the presence of regular menstruation were not associated with the incidence of headaches as described in the literature ${ }^{4,23,24}$.

Unlike gender, which is often associated with headaches in the literature ${ }^{1,4,5}$, other variables have not yet been consolidated as significantly associated with the incidence of headaches, and different studies have shown contradictory results. Thus, it is emphasized that there was no association between the incidence of headache and white skin (Caucasian) as reported by the study of Pahim and collaborators ${ }^{4}$. Similarly, socioeconomic level was not significantly associated as demonstrated by Silberstein and collaborators ${ }^{25}$ and Queiroz and collaborators ${ }^{5}$. Schooling level was another variable measured which showed no influence on this health problem, while Silva and collaborators ${ }^{1}$ indicated the opposite.

On the other hand, occupation was a determining fac- 
Table 5. Statistical tests performed to determine associations between variables.

\begin{tabular}{|c|c|c|c|c|}
\hline \multirow[b]{2}{*}{ Characteristic } & & \multicolumn{2}{|c|}{ Complaints of headaches $(n=240)$} & \multirow[b]{2}{*}{$\mathrm{p}$} \\
\hline & & Yes (\%) & No $(\%)$ & \\
\hline Gender & $\begin{array}{l}\text { Female } \\
\text { Male }\end{array}$ & $\begin{array}{l}123(79.4) \\
32(20.6)\end{array}$ & $\begin{array}{l}48(56.5) \\
37(43.5)\end{array}$ & $0.0002^{*}$ \\
\hline Occupation & $\begin{array}{l}\text { Retirees or pensioners } \\
\text { Others }\end{array}$ & $\begin{array}{l}27(17.4) \\
128(82.6)\end{array}$ & $\begin{array}{l}27(31.7) \\
58(68.3)\end{array}$ & $0.0109^{*}$ \\
\hline Mean age ${ }^{1}$ & & $39.7 \pm 14.6$ & $45.3 \pm 17.2$ & \\
\hline Color of skin & $\begin{array}{l}\text { White (Caucasian) } \\
\text { Non-white }\end{array}$ & $\begin{array}{l}146(94.2) \\
9(5.8)\end{array}$ & $\begin{array}{c}81(95.3) \\
4(4.7)\end{array}$ & 0.7186 \\
\hline Schooling & $\begin{array}{l}\text { Up to primary school } \\
\text { High school or higher education }\end{array}$ & $\begin{array}{l}73(47 \%) \\
82(53 \%)\end{array}$ & $\begin{array}{c}39(45.8) \\
46(54.1 \%)\end{array}$ & 0.8569 \\
\hline Economic classification* & $\begin{array}{l}\text { A or B } \\
\text { Cor lower }\end{array}$ & $\begin{array}{l}67(43.2) \\
88(56.8)\end{array}$ & $\begin{array}{l}36(42.3) \\
49(57.7)\end{array}$ & 0.8960 \\
\hline Marital status & $\begin{array}{l}\text { Divorced or widow/ers } \\
\text { Others }\end{array}$ & $\begin{array}{l}25(16.1) \\
130(83.9)\end{array}$ & $\begin{array}{l}13(15.3) \\
72(84.7)\end{array}$ & 0.8654 \\
\hline Living with & $\begin{array}{l}\text { Alone } \\
\text { Others }\end{array}$ & $\begin{array}{c}19(12.3) \\
136(87.7)\end{array}$ & $\begin{array}{c}8(9.4) \\
77(90.6)\end{array}$ & 0.5045 \\
\hline Use of oral contraceptive & $\begin{array}{l}\text { Yes } \\
\text { No }\end{array}$ & $\begin{array}{l}45(36.6) \\
78(63.4)\end{array}$ & $\begin{array}{l}15(31.3) \\
33(68.8)\end{array}$ & 0.5112 \\
\hline Regular menstruation & $\begin{array}{l}\text { Yes } \\
\text { No }\end{array}$ & $\begin{array}{l}74(60.2) \\
49(39.8)\end{array}$ & $\begin{array}{l}24(50.0) \\
24(50.0)\end{array}$ & 0.2273 \\
\hline Hypertension & $\begin{array}{l}\text { Yes } \\
\text { No }\end{array}$ & $\begin{array}{c}24(15.5) \\
131(84.5)\end{array}$ & $\begin{array}{l}13(15.3) \\
72(84.7) \\
\end{array}$ & 0.9689 \\
\hline & & \multicolumn{2}{|c|}{ Midas $(n=155)$} & \\
\hline Characteristic & & 1 or $2(\%)$ & 3 or $4(\%)$ & $\mathrm{p}$ \\
\hline Age & $\begin{array}{l}\text { Up to } 41 \text { years } \\
\text { Above } 41 \text { years }\end{array}$ & $\begin{array}{l}76(54.7) \\
63(45.3)\end{array}$ & $\begin{array}{l}9(56.2) \\
7(43.8)\end{array}$ & 0.9046 \\
\hline Intensity of pain & $\begin{array}{l}\text { Mild } \\
\text { Moderate or severe }\end{array}$ & $\begin{array}{l}45(32.4) \\
94(67.6)\end{array}$ & $\begin{array}{c}0(0.0) \\
16(100.0)\end{array}$ & $0.0069^{*}$ \\
\hline Gender & $\begin{array}{l}\text { Female } \\
\text { Male }\end{array}$ & $\begin{array}{l}108(77.7) \\
31(22.3)\end{array}$ & $\begin{array}{c}15(93.8) \\
1(6.2)\end{array}$ & 0.1330 \\
\hline Occupation & $\begin{array}{l}\text { Retirees or pensioners } \\
\text { Others }\end{array}$ & $\begin{array}{c}23(16.6) \\
116(83.4)\end{array}$ & $\begin{array}{c}4(25.0) \\
12(75.0)\end{array}$ & 0.3985 \\
\hline Headache duration & $\begin{array}{l}\text { For hours } \\
\text { Exceeding days }\end{array}$ & $\begin{array}{l}98(70.5) \\
41(29.5)\end{array}$ & $\begin{array}{l}8(50.0) \\
8(50.0)\end{array}$ & 0.0948 \\
\hline Non-pharmacological management & $\begin{array}{l}\text { Yes } \\
\text { No }\end{array}$ & $\begin{array}{c}35(25.2) \\
104(74.8)\end{array}$ & $\begin{array}{c}5(31.2) \\
11(68.8)\end{array}$ & 0.5992 \\
\hline Pharmacological management 2 & $\begin{array}{l}\text { Yes } \\
\text { No }\end{array}$ & $\begin{array}{c}120(86.3) \\
19(13.7)\end{array}$ & $\begin{array}{l}14(87.5) \\
2(12.5)\end{array}$ & 0.8970 \\
\hline Use of prescription drugs & $\begin{array}{l}\text { Yes } \\
\text { No }\end{array}$ & $\begin{array}{c}48(29.8) \\
113(70.2)\end{array}$ & $\begin{array}{c}9(36.0) \\
16(64.0)\end{array}$ & 0.5325 \\
\hline Use of current prescriptions & $\begin{array}{l}\text { Yes } \\
\text { No }\end{array}$ & $\begin{array}{l}11(22.4) \\
38(77.6)\end{array}$ & $\begin{array}{l}5(55.6) \\
4(44.4)\end{array}$ & $0.0411^{*}$ \\
\hline $\begin{array}{l}\text { Use of medications only } \\
\text { during headache crisis }\end{array}$ & $\begin{array}{l}\text { Yes } \\
\text { No }\end{array}$ & $\begin{array}{l}134(83.2) \\
27(16.8)\end{array}$ & $\begin{array}{l}16(64.0) \\
9(36.0)\end{array}$ & $0.0236^{*}$ \\
\hline Headache improvement & $\begin{array}{l}\text { Yes } \\
\text { No }\end{array}$ & $\begin{array}{l}119(78.8) \\
32(21.2)\end{array}$ & $\begin{array}{c}5(23.8) \\
16(76.2)\end{array}$ & $0.0000^{*}$ \\
\hline
\end{tabular}

'Analysis of variance; for the other variables chi-square test was used. *Statistically significant associations ( $p<0.05)$. **Bazilian Economic Classification ${ }^{15}$. 
tor for headache. The fact that active employees showed greater tendency to develop headaches than pensioners and retirees can suggest that they are more heavily exposed to triggering and aggravating factors. These factors include, for example, emotional stress in the workplace, which, however, was reported as irrelevant by Domingues and collaborators ${ }^{12}$.

Analysis of variance was used to compare variables and it revealed that mean age of the group that reported headache and one that had not reported it was significantly different. Younger individuals have greater tendency to suffer from headaches than the older, an association which was not found by Pahim and collaborators ${ }^{4}$. This may be related to the fact that these individuals are in the active phase of life, with greater responsibility and exposed to a greater degree of stress, while most of the older are retirees or pensioners.

The Midas score used to measure disability caused by headaches on individuals' lives revealed to be generally low, a result which is different from that found in another study in which $58.6 \%$ of subjects with migraine had severe disability as measured by the Midas ${ }^{26}$ score, highly superior to the results shown in this study.

The value found in this study is close to the results obtained by Miranda and collaborators ${ }^{13}$, who carried out a survey with regular exercise practitioners, as well as those found by Lucas and collaborators ${ }^{27}$. The degree of disability indicated by the total Midas score was positively proportional to pain intensity reported by individuals, i.e., the higher the score, the more severe is the pain, a result which is different from that presented in the literature ${ }^{26}$.

Through the characteristics of headaches reported by subjects in the study, such as type of pain, location, triggering and aggravating factors, and management used, in addition to the data available in the literature $e^{17,18,25}$, it could be possible to suggest that the sample has a high percentage of tension-type headache and migraine. Confirmation of these assumptions corroborates other studies, which have shown that these types of headaches are common among the general population ${ }^{4}$, and among the age group 5 investigated.

A predominance of pharmacological management over non-pharmacological measures, such as the use of compresses, was observed. The latter represented a small percentage when compared to the study of Miranda and collaborators $^{13}$, in which $70 \%$ of individuals reported bed resting when affected by headaches. The use of medications, mainly common over-the-counter painkillers, was observed especially in acute crisis. The most frequently used drug was paracetamol, followed by dipyrone sodium, mentioned in various studies as the most common option for headache management ${ }^{12,28}$.

Through statistical analysis, significant difference was observed between those who had a lower degree of disability according to the Midas score and those who used drugs only in acute crisis with effective improvement. This is expected because when headaches do not interfere with the individuals' daily lives and when it is easy to handle should they occur, there is no need for a prophylactic treatment. It was also observed that individuals with higher Midas scores make use of current prescriptions, which is probably resulting from more frequent medical monitoring.

Others make use of self-medication through old medical prescriptions or through information on medicines from lay individuals and health professionals, situation which is described in the literature for the treatment of minor disorders ${ }^{12,22}$. In a study conducted in a city of western Santa Catarina, Pizzatto and collaborators ${ }^{23}$ showed that $77.3 \%$ of respondents with headache reported selfmedication for pain relief. Corroborating high rates of self-medication for headache management, Vilariño and collaborators ${ }^{29}$ determined the profile of self-medication in a city of southern Brazil, where headaches were mentioned as the major reason for self-medication, being analgesics, antipyretics and non-steroidal anti-inflammatory drugs the most frequently used.

Self-medication based on the indiscriminate and sometimes abusive use of common painkillers, besides exposing the individual to all kind of related risks, can be a precipitating factor for chronic daily headache ${ }^{30,31}$. However, the correlation between the daily use of analgesics and daily headache was not statistically significant $(p=0.0898)$ in this study. Nonetheless, this fact deserves further investigation.

Considering the high self-medication rate, it is evident that a great distance exists between the individual with headache and the establishment of an effective treatment that leads to headache prevention or improvement. Health care systems and their professionals should provide guidance, promotion of rational use of medicines and adoption of non-pharmacological measures to improve individuals' quality of life.

Despite methodological limitations already mentioned, it can be concluded that there is high prevalence of headaches among the population studied, especially among women. Headaches also occur among younger individuals, a fact possibly explained by being professionally active and consequently exposed to a greater number of stressful factors. Headache management was primarily pharmacological, particularly through self-medication, while a small portion of individuals performed a regular treatment monitored by health care professionals. The impact on most individuals' lives was small or absent, and when severe it was associated with intense pain. Thus, the development of further research on the topic is 
central to the clarification of issues not addressed in this study and can significantly contribute for the rational use of medicines in the management of headaches.

ACKNOWLEDGMENTS - The authors are grateful to Dr. Jefferson Luiz Traebert and Dr. Anna Paula Piovezan for their input and helpful discussions. Thanks also go to Dr. Wilson Schuelter for the translation into English.

\section{REFERENCES}

1. Silva FS, Sampaio MCF, Neto JC, et al. Prevalência de cefaléia no transcorrer da vida em uma amostra da população da região metropolitana de Recife. Migrâneas Cefaléias 2005:8:104-106.

2. Souza JA, Moreira Filho PF, Jevoux CC, et al. Idade como fator de risco independente para cefaléias secundárias. Arq Neuropsiquiatr 2004;62:1038-1045.

3. Gorayeb MAM, Gorayeb R. Cefaléia associada a indicadores de transtornos de ansiedade em uma amostra de escolares de Ribeirão Preto, SP. Arq Neuropsiquiatr 2002;60:764-768.

4. Pahim LS, Menezes AMB, Lima R. Prevalência e fatores associados à enxaqueca na população adulta de Pelotas, RS. Rev Saúde Públ 2006;40:692-698.

5. Queiroz LP, Barea LM, Blank N. An epidemiological study of headache in Florianopolis, Brazil. Cephalalgia 2006;26:122-127.

6. Tietjen GE, Brandes JL, Digre KB, et al. High prevalence of somatic symptoms and depression in women with disabling chronic headache. Neurology 2007;68:134-140.

7. Macgregor EA, Hackshaw A. Prevalence of migraine on each day of the natural menstrual cycle. Neurology 2004;63:351-353.

8. Saunders K, Merikangas K, Low NCP, et al. Impact of comorbidity on headache-related disability. Neurology 2008;70:538-547.

9. Lipton RB, Bigal ME, Kolodner K, et al. The family impact of migraine: population-based studies in the USA and UK. Cephalalgia 2003;23:429-440.

10. Lipton RB, Stewart WF. The Migraine Disability Assessment Test. Disponível em: http://www.uhs.berkeley.edu/home/healthtopics/pdf/assessment.pdf. Acesso: August 29, 2008.

11. Fragoso YD. MIDAS (Migraine Disability Assessment): a valuable tool for work-site identification of migraine in workers in Brazil. Rev Paul Med 2002;120:118-121.

12. Domingues RB, Kuster GW, Dutra LA, et al. Headache epidemiology in Vitória, Espírito Santo. Arq Neuropsiquiatr 2004;62:588-591.

13. Miranda F, Dantas B, Krymchantowski AV. Prevalência e características da cefaléia em uma população de praticantes regulares de exercícios físicos. Arq Neuropsiquiatr 2006;64:802-806.
14. Morelli JGS, Rebelatto JR. A eficácia da terapia manual em indivíduos cefaleicos portadores e não-portadores de degeneração cervical: análise de seis casos. Rev Bras Fisioter 2007;11:325-329.

15. Wink S, Cartana MHF. Promovendo o autocuidado a pacientes com cefaléia por meio da perspectiva oriental de saúde. Rev Bras Enferm 2007;60: 225-228.

16. Associação Brasileira de Empresas de Pesquisa. Critério de Classificação Econômica Brasil. Disponível em: http://www.abep.org/codigosguias/ Criterio_Brasil_2008.pdf. Acesso: April 22, 2009.

17. Headache classification committee of the international headache society. Classification and diagnostic criteria for headache disorders, cranial neuralgias and facial pain. Cephalalgia 2004;24:1-150.

18. Sociedade Brasileira de Cefaléia. Tipos de dor de cabeça. Available at: http:// www.sbce.med.br/index.asp. Acessed: August 30, 2008.

19. Maranhão-Filho P. A anamnese das cefaléias. Migrâneas Cefaléias 2006;9:18-22.

20. Thomson F. Neurological disorders In: Lee A (Ed). Adverse drug reactions. London: Pharmaceutical Press, 2001:240-266.

21. Bigal ME, Bigal JOM, Bordini CA, et al. Prevalence and costs of headaches for the public health system in a town in the interior of the state of São Paulo. Arq Neuropsiquiatr 2001;59:504-511.

22. Pizzatto M, Silva MR, Traebert J. Cefaléia associada a indicadores de transtornos de ansiedade em uma população adulta da região Sul do Brasil: estudo de base populacional. Rev Soc Bra Clin Med 2008;6:15-20.

23. Aegidius K, Zwart JA, Hagen K, et al. Oral contraceptives and increased headache prevalence. The Head-HUNT Study. Neurology 2006;66:349-353.

24. Fukui PT, Gonçalves TRT, Strabelli CG, et al. Trigger factors in migraine patients. Arq Neuropsiquiatr 2008;66:494-499.

25. Silberstein S, Loder E, Diamond S, et al. Probable migraine in the United States: results of the American Migraine Prevalence and Prevention (AMPP) Study. Cephalalgia 2007;27:220-229.

26. Fernández-Concepción O, Canuet-Delis L. Discapacidad y calidad de vida en pacientes con migraña: factores determinantes. Rev Neurol 2003;36: 1105-1112.

27. Lucas C, Chaffaut C, Artaz MA, et al. FRAMIG 2000: medical and therapeutic management of migraine in France. Cephalalgia 2005;25:267-279.

28. Ruiz Jr BF, Santos SM, Siqueira SH, et al. Clinical features, diagnosis and treatment of acute primary headaches at an emergency center: why are we still neglecting the evidence? Arq Neuropsiquiatr 2007;65:1130-1133.

29. Vilarino JF, Soares IC, Silveira CM, et al. Perfil da automedicação em município do Sul do Brasil. Rev Saúde Públ 1998;32:43-49.

30. Colás R, Muñoz P, Temprano R, et al. Chronic daily headache with analgesic overuse. Neurology 2004;62:1338-1342.

31. Zwart JA, Dyb G, Hagen K, et al. Analgesic overuse among subjects with headache, neck, and low-back pain. Neurology 2004;62:1540-1544. 